\title{
Preservice Teachers' Entry Credentials, SATT Performance and Academic Achievement: A Discriminant Analysis
}

\author{
Velma S. Labad, Juse Lyn P. Hiponia, \\ and Bonifacio G. Gabales, Jr.'
}

\begin{abstract}
This study ascertains the discriminant model that could best explain preservice teachers' academic achievement. Using the University of Southeastern Philippines Admission Test (USePAT) and Standardized Admission Test for Teachers (SATT) results as predictor variables, a descriptive-discriminant research design was used involving 771 preservice teachers in a span of 3 school years. Variables entered in the discriminant model were numerical, verbal (SATT constructs), abstract, and general information (USePAT constructs). It is recommended that the University should revisit the USePAT to determine other measures as entry requirements in lieu of the ratings in the content subjects - English, Math and Science - as these did not figure into the discriminant model.
\end{abstract}

Keywords: preservice teachers, discriminant model, entry credentials

The authors are faculty of the College of Education of the University of Southeastern Philippines.

Contact the lead author at velma.labad@usep.edu.ph 
In the globalized race for better student achievement, quality of teaching has the greatest systemic effect on students' achievement (Hanushek, 2011 in Wright, 2015). In the study of Alton-Lee (2003 in Wright, 2015), it was found out that teachers contribute 30 percent on average to increases in student achievement; for students with greatest need, the impact is as high as 60 percent. In a nutshell, teachers matter (Wright, 2015).

Zumwalt and Craig (2005 in Hall \& West, 2011) note that "policy makers, politicians and government officials, leaders of the business and philanthropic communities, and educators at all levels have worked to raise standards for prospective teachers and upgrade teacher education programs." The efforts have focused on the intellectual ability of teacher candidates. For instance, raising minimum GPA requirements for acceptance into teacher education programs - this effort eliminates teacher candidates with questionable academic performance. Similarly, using college entrance exam scores (in the United States, SATT or Standardized Aptitude Test for Teachers and ACT or American College Test) is a common method to determine a candidate's academic ability.

These reform efforts of increased standards for teacher education program admission help make the teaching profession less of a "dumping ground for low achievers". More recently, teacher tests have been greatly emphasized and utilized to determine the intellectual competence, particularly the subject matter and pedagogical knowledge of those entering the program (Zumwalt \& Craig, 2005 in Hall \& West, 2011). These efforts aimed to increase the profile of teacher candidates to have better student achievement.

In the United States, teacher preparation accrediting bodies crafted ten principles for assessment, which they hope would reflect the knowledge, skills, and disposition that aspiring teachers should possess. These principles include: (1) content pedagogy, or the teachers' 
understanding of the central concepts, tools of inquiry, and structures of the discipline they teach as well as their capability to create learning experiences that enable these aspects of subject matter significant for students; (2) student development, or the teachers' understanding of how children learn and develop, and their capability to offer learning opportunities that support the children's intellectual, social, and personal development; (3) diverse learners, or the teachers' understanding of how students differ in their approaches to learning and their capability to create instructional opportunities that are adapted to diverse learners; (4) multiple instruction strategies, or the teachers' understanding and usage of a variety of instructional strategies to encourage student development of critical thinking, problem solving, and performance skills; (5) motivation and management, or the teachers' understanding of individual and group motivation and behavior to provide a learning environment that encourages positive social interaction, active engagement in learning, and self-motivation; (6) communication and technology, or the teachers' use of their knowledge of effective verbal, nonverbal, and media communication techniques to nurture active inquiry, collaboration, and supportive classroom interaction; (7) planning, or the teachers' planned instruction anchored on their knowledge of the subject matter and curriculum goals as well as of the students and community; (8) assessment, or the teachers' understanding and usage of formal and informal assessment strategies to evaluate and ensure the continuous intellectual, social, and physical development of the learner; (9) reflective practice, or the teachers' continuous reflection and evaluation of the effects of their choices and actions on the learning community and their seeking out actively of opportunities to grow professionally; and (10) school and community involvement, or the teachers' capability to foster relationships with the school stakeholders to support students' learning and wellbeing (Interstate New Teacher Assessment and Support Consortium [INTASC], 1992, in Hall \& West, 2011). 
Closely related to those is teacher's competence, which is dependent on the level of education as well as the professional training of teachers (UNESCO World Survey, in Ambag, 2015). In the Philippines Article 1 Section 1 of Republic Act 7722 states that quality preservice teacher education is crucial in quality Philippine education. In response to RA 7722's challenge, the teacher education curriculum was revised, pursuant to CHED Memorandum Order No. 30, s. 2004. The integration of theoretical, methodological and experiential components of the curriculum was the significant change in the design of professional education courses (De Leon, 2010 in Ambag, 2015). Consequently, the Department of Education introduced the National Competency-Based Standards for Teachers (NCBTS). This is a framework that establishes the competency standards for teacher performance for teachers, learners and stakeholders to appreciate the complex set of behaviors, attitudes and skills that each teacher must possess to carry out a satisfactory performance of their roles and responsibilities (DepED, NCBTS Teachers' Strength and Needs Assessment, in Ambag, 2015). The framework is based upon the core values of Filipino teachers and on the principles of effective teaching and learning which are categorized into domains representing the desired features of the teaching and learning process. At present though, the DepEd utilizes the Philippine Professional Standards for Teachers (PPST), based on DepEd Order No. 42, s. 2017. This change is "brought about by various national and global frameworks such as the $\mathrm{K}$ to 12 reform, ASEAN integration, globalization, and the changing character of the $21^{\text {st }}$ century learners".

As stated earlier, teacher preparation is crucial, thus USeP (University of Southeastern Philippines), specifically CEd (College of Education) students are demanded to reach a grade of 85\% in English, Science and Math as well as in their General Weighted Average (GWA). Moreover, their USePAT (the Admission Test of the University) overall 
result score should be 5, with the same minimum rating in English, Science and Math. By their second year in the University, the SATT (Standardized Admission Test for Teachers) is administered to them, although this particular test has no bearing in their standing in the College and the University in general. This study nonetheless intends to find out whether these entry credentials and SATT performance could best explain students' academic achievement. The findings of the study were meant to help administrators enhance the implementation of university policies. This becomes even more urgent in the light of the full implementation of the K to 12 curriculum of DepEd.

The primary concern was to ascertain which variables can best explain preservice teachers' (PSTs) academic achievement. Specifically, it sought to find out: (1) the profile of the preservice teachers' USePAT ratings in English, Math, Science, General Information, Abstract Reasoning, and Overall USePAT; (2) the profile of the preservice teachers' performance in SATT; (3) the profile of the preservice teachers' academic achievement; (4) the significant difference of the students' USePAT ratings and SATT when they are grouped according to their fields of specialization; and (5) the discriminant model that can best explain preservice teachers' academic achievement.

\section{Method}

Descriptive-discriminant method was utilized in this study. According to Williams (2007), descriptive research is a basic method that examines a situation as it occurs in its present state. It involves identification of characteristics of a particular occurrence on an observational basis, or the examination of relationship between two or more phenomena. On the other hand, discriminant analysis determines a set of prediction equations centered on independent variables that 
are used to categorize individuals into groups. There are two probable objectives in a discriminant analysis: defining a predictive equation to classify new individuals or interpreting the predictive equation to better understand the relations that may occur among the variables (Chapter 440, Discriminant Analysis, n.d.).

The respondents of the study were the preservice teachers who graduated in SYs2013-2016. The study involved 771 PSTs in a span of three school years. The figure below shows the percent distribution of respondents, according to school year and specialization.

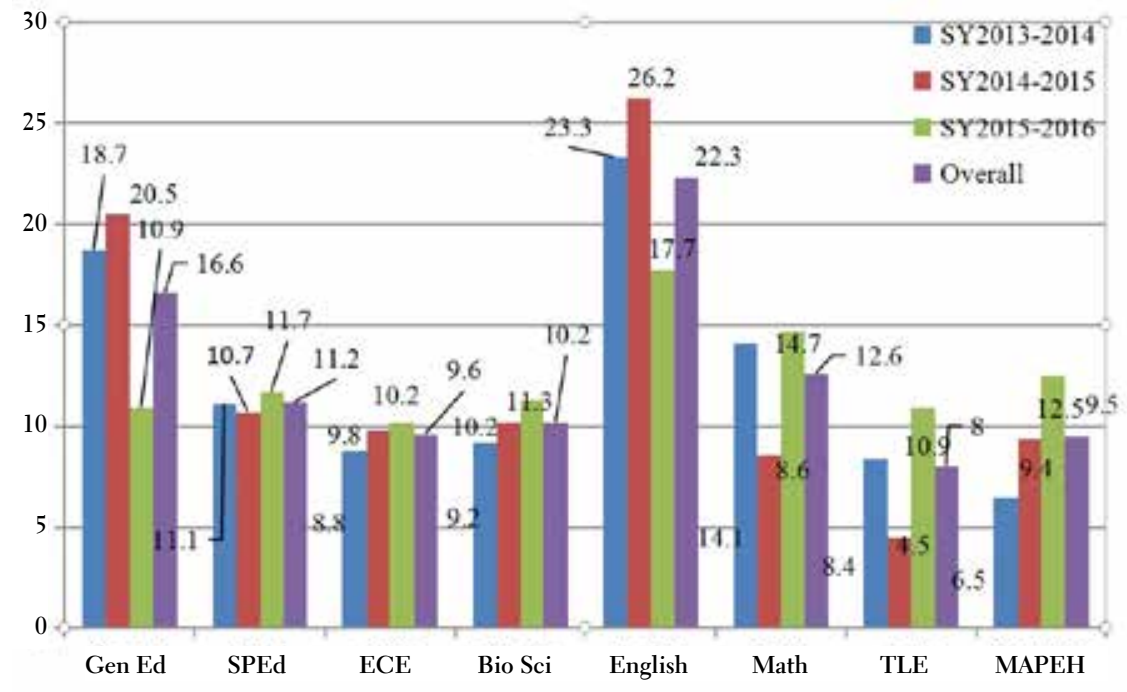

\section{Figure 1}

Distribution of respondents by major/specialization per school year

The numerical distribution of respondents involved: 262 PSTs for SY2013-2014; 244 PSTs for SY2014-2015; and 265 PSTs for SY20152016. The study considered the total population; however due to incomplete data only 771 student-teachers were tallied as final number of respondents. All preservice teachers in three consecutive years had been asked to be part of the research activity but only 85 percent were 
included. They were asked to sign an informed consent for utilization of their records as data for the study.

The study used secondary data of three intact groups across three school years. Scholastic data were measured using the following instruments: USePAT scores in English, Math, Science, Abstract Reasoning, General Information and the Overall scores; SATT scores both from the intellective and non-intellective results; and the academic achievement of the student teachers in terms of their overall weighted average.

The statistical tools used were: mean and standard deviation to describe the profile of the students' USePAT and SATT ratings; Pearson product moment correlation (Pearson $r$ ) to describe the degree of relationships between the independent and dependent variables; Analysis of Variance (ANOVA) to resolve whether or not there is a significant difference when the respondents are grouped according to their field of specialization; Discriminant analysis to identify which of the variables could discriminate the student-teachers academic achievement $(0=$ low; l=average; $2=$ high).

\section{Results and Discussion}

\section{Profile of the preservice teachers' USePAT ratings}

Table 1 presents the profile of the preservice teachers' USePAT ratings for three consecutive years. It can be gleaned from Table 1 that the overall USePAT rating in English (Mean=3.17, $\mathrm{SD}=.487$ ); Math (Mean=3.07, SD=.637); General Information (Mean=3.13, $\mathrm{SD}=.797$ ); Abstract Reasoning (Mean=2.91, SD=.923); and Overall rating (Mean=3.16, $\mathrm{SD}=.418$ ) have descriptive equivalents of average. However, in Science, the preservice teachers had a descriptive equivalent of low (Mean=2.39, SD=.921). It is worth noting that in SYs2013-2014 (Mean=1.96, SD=.726) and 2015-2016 (Mean=1.97, SD=.679), the 
preservice teachers' rating in Science had a low descriptive equivalent. However, in SY 2014-2015, it had a descriptive equivalent of average (Mean=3.29, $\mathrm{SD}=.645$ ). The result implies that generally, students who were accepted to join the ranks of preservice teachers were average students based on their USePAT scores.

Table 1. Profile of the preservice teachers' USePAT ratings

\begin{tabular}{|c|c|c|c|c|c|c|c|c|}
\hline \multirow[t]{2}{*}{$\begin{array}{l}\text { USePAT } \\
\text { constructs }\end{array}$} & \multicolumn{2}{|c|}{$\begin{array}{c}\text { SY2013-2014 } \\
(n=262)\end{array}$} & \multicolumn{2}{|c|}{$\begin{array}{c}\text { SY2014-2015 } \\
(n=244)\end{array}$} & \multicolumn{2}{|c|}{$\begin{array}{c}\text { SY2015-2016 } \\
(n=265)\end{array}$} & \multicolumn{2}{|c|}{$\begin{array}{c}\text { Overall } \\
n=771)\end{array}$} \\
\hline & Mean & $\begin{array}{l}\text { Std. } \\
\text { Dev. }\end{array}$ & Mean & $\begin{array}{l}\text { Std. } \\
\text { Dev. }\end{array}$ & Mean & $\begin{array}{l}\text { Std. } \\
\text { Dev. }\end{array}$ & Mean & $\begin{array}{l}\text { Std. } \\
\text { Dev. }\end{array}$ \\
\hline English & 3.14 & 1.814 & 3.47 & .624 & 3.03 & .351 & 3.17 & .487 \\
\hline Math & 3.00 & .652 & 3.20 & .609 & 3.01 & .630 & 3.07 & .637 \\
\hline Science & 1.96 & .726 & 3.29 & .645 & 1.97 & .679 & 2.39 & .921 \\
\hline $\begin{array}{l}\text { General In- } \\
\text { formation }\end{array}$ & 2.90 & .759 & 3.47 & .766 & 3.04 & .757 & 3.13 & .797 \\
\hline $\begin{array}{l}\text { Abstract } \\
\text { reasoning }\end{array}$ & 3.04 & .910 & 2.50 & .818 & 3.15 & .905 & 2.91 & .923 \\
\hline $\begin{array}{l}\text { Overall } \\
\text { USePAT }\end{array}$ & 3.04 & .219 & 3.40 & .590 & 3.05 & .247 & 3.16 & .418 \\
\hline $\begin{array}{l}.00-1.50 \text {-Very } 1 \\
1.51-2.50 \text {-Low } \\
2.51-3.50 \text {-Aver } \\
\text { 3.51-4.50-High } \\
4.51-5.00 \text {-Very }\end{array}$ & & & & & & & & \\
\hline
\end{tabular}

\section{Profile of the preservice teachers' SATT performance}

Table 2 shows the profile of the preservice teachers' SATT intellective ability ratings. The overall score shows a descriptive equivalent of high average in Verbal (Mean=3.03, $\mathrm{SD}=.828$ ), Numerical (Mean=2.88, $\mathrm{SD}=.793$ ), Reading comprehension (Mean=3.22, $\mathrm{SD}=.739$ ), Abstract reasoning (Mean=3.44, $\mathrm{SD}=.674$ ), and Overall intellective ability (Mean=3.23, SD=.696). But in Judging and teaching situation (Mean=2.36, $\mathrm{SD}=1.141$ ), the preservice teachers had a descriptive equivalent of low average. 
Table 2. Profile of the preservice teachers' SATT intellective ability ratings

\begin{tabular}{|c|c|c|c|c|c|c|c|c|}
\hline \multirow[b]{2}{*}{$\begin{array}{c}\text { SATT } \\
\text { intellec- } \\
\text { tive } \\
\text { ability }\end{array}$} & \multicolumn{2}{|c|}{$\begin{array}{c}\text { SY2013-2014 } \\
(n=262)\end{array}$} & \multicolumn{2}{|c|}{$\begin{array}{c}\text { SY2014-2015 } \\
(n=244)\end{array}$} & \multicolumn{2}{|c|}{$\begin{array}{l}\text { SY2015-2016 } \\
(n=265)\end{array}$} & \multicolumn{2}{|c|}{$\begin{array}{l}\text { Overall } \\
(n=771)\end{array}$} \\
\hline & Mean & $\begin{array}{l}\text { Std. } \\
\text { Dev. }\end{array}$ & Mean & $\begin{array}{l}\text { Std. } \\
\text { Dev. }\end{array}$ & Mean & $\begin{array}{l}\text { Std. } \\
\text { Dev. }\end{array}$ & Mean & $\begin{array}{l}\text { Std. } \\
\text { Dev. }\end{array}$ \\
\hline Verbal & 3.29 & .711 & 2.31 & .618 & 3.45 & .661 & 3.03 & .828 \\
\hline Numerical & 3.03 & .736 & 2.31 & .637 & 3.24 & .689 & 2.88 & .793 \\
\hline $\begin{array}{l}\text { Judging } \\
\text { and } \\
\text { teaching } \\
\text { situation }\end{array}$ & 2.58 & 1.240 & 1.92 & .854 & 2.03 & .272 & 2.36 & 1.141 \\
\hline $\begin{array}{l}\text { Reading } \\
\text { compre- } \\
\text { hension }\end{array}$ & 3.57 & .593 & 2.63 & .516 & 3.41 & .718 & 3.22 & .739 \\
\hline $\begin{array}{l}\text { Abstract } \\
\text { reasoning }\end{array}$ & 3.78 & .454 & 2.79 & .470 & 3.71 & .584 & 3.44 & .674 \\
\hline $\begin{array}{l}\text { Overall } \\
\text { intellec- } \\
\text { tive } \\
\text { ability }\end{array}$ & 3.59 & .551 & 2.68 & .474 & 3.40 & .685 & 3.23 & .696 \\
\hline $\begin{array}{l}\text { 1-1.50-Low } \\
1.51-2.50-\mathrm{Low} \\
2.51-3.50-\mathrm{Hig} \\
3.51-4.00-\mathrm{Hig}\end{array}$ & $\begin{array}{l}\text { rage } \\
\text { erage }\end{array}$ & & & & & & & \\
\hline
\end{tabular}

Table 3 presents the profile of the preservice teachers' SATT non-intellective skills ratings. The following sub-skills: Management (Mean=2.85, SD=1.036), Communication (Mean=2.65, SD=1.055), Teaching (Mean=2.65, SD=1.076), and Overall non-intellective skills (Mean=2.59, $\mathrm{SD}=1.058$ ) had a descriptive equivalent of high average. However, the sub-skills Human relations (Mean=2.43, SD=1.127) and Values (Mean=2.10, SD=1.004) had a descriptive equivalent of low average. 
Table 3. Profile of the preservice teachers' SATT non-intellective skills ratings

\begin{tabular}{|c|c|c|c|c|c|c|c|c|}
\hline \multirow{2}{*}{$\underset{\substack{\text { SATT } \\
\text { non-intellec- } \\
\text { tive skills }}}{ }$} & \multicolumn{2}{|c|}{$\underset{(n=262)}{S Y 2013-2014}$} & \multicolumn{2}{|c|}{$\underset{(n=244)}{\text { SY204-2015 }}$} & \multicolumn{2}{|c|}{$\underset{(n=265)}{S Y 2015-2016)}$} & \multicolumn{2}{|c|}{$\begin{array}{c}\text { Overall } \\
(\mathrm{n}=771)\end{array}$} \\
\hline & Mean & $\begin{array}{l}\text { Std. } \\
\text { Dev. }\end{array}$ & Mean & $\begin{array}{l}\text { Std. } \\
\text { Dev. }\end{array}$ & Mean & $\begin{array}{l}\text { Std. } \\
\text { Dev. }\end{array}$ & Mean & $\begin{array}{l}\text { Std. } \\
\text { Dev. }\end{array}$ \\
\hline Management & 3.19 & 1.030 & 2.51 & .761 & 2.84 & 1.151 & 2.85 & 1.036 \\
\hline $\begin{array}{l}\text { Communica- } \\
\text { tion }\end{array}$ & 2.98 & 1.050 & 2.37 & .839 & 2.57 & 1.149 & 2.65 & 1.055 \\
\hline Teaching & 3.12 & 1.089 & 2.47 & .782 & 2.70 & 1.195 & 2.77 & 1.076 \\
\hline $\begin{array}{l}\text { Human } \\
\text { relations }\end{array}$ & 2.79 & 1.116 & 2.11 & .883 & 2.36 & 1.239 & 2.43 & 1.127 \\
\hline Values & 2.42 & 1.050 & 1.86 & .785 & 2.00 & 1.058 & 2.10 & 1.004 \\
\hline $\begin{array}{l}\text { Overall } \\
\text { non-intellec- } \\
\text { tive skills }\end{array}$ & 2.92 & 1.071 & 2.36 & .817 & 2.46 & 1.157 & 2.59 & 1.058 \\
\hline
\end{tabular}

01-1.50-Low

1.51-2.50-Low average

2.51-3.50-High average

3.51-4.00-High

Table 4 shows the profile of the preservice teachers' overall SATT performance. It shows that preservice teachers' overall SATT (Mean=2.95, SD=812) performance had a descriptive equivalent of high average.

Table 4. Profile of the preservice teachers' overall SATT performance

\begin{tabular}{|c|c|c|c|c|c|c|c|c|}
\hline & \multicolumn{2}{|c|}{$\underset{(n=262)}{S Y 2013-2014}$} & \multicolumn{2}{|c|}{$\underset{(n-244)}{S Y 2014-2015}$} & \multicolumn{2}{|c|}{$\underset{(n=265)}{S Y 2015-2016}$} & \multicolumn{2}{|c|}{ Overall $(n=771)$} \\
\hline & Mean & $\begin{array}{l}\text { Std. } \\
\text { Dev. }\end{array}$ & Mean & $\begin{array}{l}\text { Std. } \\
\text { Dev. }\end{array}$ & Mean & $\begin{array}{l}\text { Std. } \\
\text { Dev. }\end{array}$ & Mean & $\begin{array}{l}\text { Std. } \\
\text { Dev. }\end{array}$ \\
\hline SATT & 3.29 & .792 & 2.58 & .613 & 2.97 & .848 & 2.95 & .812 \\
\hline $\begin{array}{l}01-1.50-\mathrm{I} \\
1.51-2.50 \\
2.51-3.50 \\
3.51-4.00\end{array}$ & $\begin{array}{l}\text { W } \\
\text { Low aver } \\
\text { High aver } \\
\text { High }\end{array}$ & & & & & & & \\
\hline
\end{tabular}

\section{Significant difference of students' USePAT and SATT rating when grouped according to their major/specialization}

Presented in Table 5 is the analysis of variance on the preservice teachers' USePAT rating when they are grouped according to field of 
specialization. The data analysis registered a significant difference in English $(\mathrm{F}=5.890$, p-value=.000), Math $(\mathrm{F}=11.201$, p-value $=.000)$, Science $(\mathrm{F}=5.651$, $\mathrm{p}$-value $=.000)$ and General Information $(\mathrm{F}=5.062$, $\mathrm{p}$-value $=.000)$, and Overall $(\mathrm{F}=3.354$, $\mathrm{p}$-value $=.002)$. Post hoc tests revealed that the difference rested on the BSEd-English, Math and Biology students. This means that generally these students have better scores in English, Math, Science, General Information (including the Overall USePAT rating) compared to the rest of the courses. These data reveal that preservice teachers differ significantly in almost all measures of the USePAT. Abstract reasoning did not manifest significant difference, which means that preservice teachers do not differ significantly in this measure.

Table 5. Analysis of Variance (ANOVA) on the preservice teachers' USePAT rating when grouped according to their field of specialization $(n=771)$

\begin{tabular}{llrrrrr}
\hline \multirow{2}{*}{ English } & Between Groups & $\begin{array}{c}\text { Sums } \\
\text { of squares }\end{array}$ & \multicolumn{1}{c}{ df } & $\begin{array}{c}\text { Mean } \\
\text { Square }\end{array}$ & F & Sig. \\
& Within Groups & 173.368 & 7 & 1.338 & 5.890 & .000 \\
& Total & 182.711 & 770 & & & \\
Math & Between Groups & 29.175 & 7 & 4.168 & 11.201 & .000 \\
& Within Groups & 283.902 & 763 & .372 & & \\
& Total & 313.077 & 770 & & & \\
Science & Between Groups & 32.232 & 7 & 4.605 & 5.651 & .000 \\
& Within Groups & 621.690 & 763 & .815 & & \\
& Total & 653.922 & 770 & & & \\
General & Between Groups & 21.744 & 7 & 3.106 & 5.062 & .000 \\
tion & Within Groups & 468.227 & 763 & .614 & & \\
Abstract & Total & 489.971 & 770 & & & \\
reasoning & Between Groups & 8.750 & 7 & 1.250 & 1.473 & .174 \\
& Within Groups & 647.600 & 763 & .849 & & \\
& Total & 656.350 & 770 & & & \\
Overall & Between Groups & 4.022 & 7 & .575 & 3.354 & .002 \\
& Within Groups & 130.712 & 763 & .171 & & \\
& Total & 134.734 & 770 & & & \\
\hline
\end{tabular}


Table 6 shows the analysis of variance on the preservice teachers' SATT intellective ability rating when grouped according to field of specialization. Results show that preservice teachers differ significantly in three of the measures of the SATT intellective ability: Verbal $(\mathrm{F}=5.989$, $\mathrm{p}$-value=.000), Numerical $(\mathrm{F}=4.824, \quad \mathrm{p}$-value=.000), and Overall Intellective $(\mathrm{F}=4.025$, $\mathrm{p}$-value $=.000)$, Post hoc tests revealed that the difference still rested on BSEd-English, Math and Biology students. This means that these students had better scores in this measure compared to the rest of the students. However, in the following constructs - Judgment and teaching $(\mathrm{F}=1.087$, $\mathrm{p}$-value $=.381)$, Reading comprehension $(\mathrm{F}=.587$, $\mathrm{p}$-value $=.767)$, and Abstract reasoning $(\mathrm{F}=1.319$, $\mathrm{p}$-value $=.238)$, the students did not register significant difference.

Table 6. Analysis of Variance (ANOVA) on the preservice teachers' intellective ability rating when grouped according to their field of specialization

\begin{tabular}{|c|c|c|c|c|c|c|}
\hline $\begin{array}{l}\text { Intellective } \\
\text { skills }\end{array}$ & & $\begin{array}{c}\text { Sums } \\
\text { of squares }\end{array}$ & df & $\begin{array}{c}\text { Mean } \\
\text { Square }\end{array}$ & $\mathbf{F}$ & Sig. \\
\hline \multirow[t]{3}{*}{ Verbal } & Between Groups & 27.544 & 7 & 3.935 & 5.989 & .000 \\
\hline & Within Groups & 501.289 & 763 & .657 & & \\
\hline & Total & 528.833 & 770 & & & \\
\hline \multirow[t]{3}{*}{ Numerical } & Between Groups & 20.556 & 7 & 2.937 & 4.824 & .000 \\
\hline & Within Groups & 464.466 & 763 & .609 & & \\
\hline & Total & 485.022 & 770 & & & \\
\hline \multirow{3}{*}{$\begin{array}{l}\text { Judgment } \\
\text { and teaching }\end{array}$} & Between Groups & 9.748 & 7 & 1.393 & 1.070 & .381 \\
\hline & Within Groups & 993.108 & 763 & 1.302 & & \\
\hline & Total & 1002.856 & 770 & & & \\
\hline \multirow{3}{*}{$\begin{array}{l}\text { Reading } \\
\text { comprehension }\end{array}$} & Between Groups & 2.252 & 7 & .322 & .587 & .767 \\
\hline & Within Groups & 418.264 & 763 & .548 & & \\
\hline & Total & 420.516 & 770 & & & \\
\hline \multirow{3}{*}{$\begin{array}{l}\text { Abstract } \\
\text { reasoning }\end{array}$} & Between Groups & 4.194 & 7 & .599 & 1.319 & .238 \\
\hline & Within Groups & 346.429 & 763 & .454 & & \\
\hline & Total & 350.623 & 770 & & & \\
\hline \multirow[t]{3}{*}{ Intellective } & Between Groups & 13.305 & 7 & 1.901 & 4.025 & .000 \\
\hline & Within Groups & 360.260 & 763 & .472 & & \\
\hline & Total & 373.564 & 770 & & & \\
\hline
\end{tabular}


Presented in Table 7 is the analysis of variance on the preservice teachers' non-intellective ability rating when they are grouped according to field of specialization. As can be gleaned from the table, only Values $(\mathrm{F}=2.367$, p-value $=.021)$ registered a significant difference. Post hoc tests revealed that GenEd, SPEd, and ECE students had better scores in Values compared to the rest of the students. The rest of the non-intellective abilities Management $(\mathrm{F}=1.908$, p-value=.066), Communication $(\mathrm{F}=1.677$, $\mathrm{p}$-value $=.111)$, teaching $(\mathrm{F}=1.331$, $\mathrm{p}$-value=.232), human relations $(\mathrm{F}=1.380$, $\mathrm{p}$-value $=.211)$, and the Overall non-intellective ability $(\mathrm{F}=1.792$, $\mathrm{p}$-value $=.086)$ registered no significant difference.

Table 7. Analysis of Variance (ANOVA) on the preservice teachers' nonintellective ability rating when grouped according to their field of specialization

\begin{tabular}{|c|c|c|c|c|c|c|}
\hline $\begin{array}{l}\text { Non-intellec- } \\
\text { tive skills }\end{array}$ & & $\begin{array}{c}\text { Sums } \\
\text { of squares }\end{array}$ & df & $\begin{array}{c}\text { Mean } \\
\text { Square }\end{array}$ & $\mathbf{F}$ & Sig. \\
\hline \multirow[t]{3}{*}{ Management } & Between Groups & 14.224 & 7 & 2.032 & 1.908 & .066 \\
\hline & Within Groups & 812.648 & 763 & 1.065 & & \\
\hline & Total & 826.872 & 770 & & & \\
\hline \multirow[t]{3}{*}{ Communication } & Between Groups & 12.991 & 7 & 1.856 & 1.677 & .111 \\
\hline & Within Groups & 844.155 & 763 & 1.106 & & \\
\hline & Total & 857.147 & 770 & & & \\
\hline \multirow[t]{3}{*}{ Teaching } & Between Groups & 10.763 & 7 & 1.538 & 1.331 & .232 \\
\hline & Within Groups & 881.418 & 763 & 1.155 & & \\
\hline & Total & 892.182 & 770 & & & \\
\hline \multirow{3}{*}{$\begin{array}{l}\text { Human } \\
\text { relations }\end{array}$} & Between Groups & 12.241 & 7 & 1.749 & 1.380 & .211 \\
\hline & Within Groups & 967.069 & 763 & 1.267 & & \\
\hline & Total & 979.310 & 770 & & & \\
\hline \multirow[t]{3}{*}{ Values } & Between Groups & 16.504 & 7 & 2.358 & 2.367 & .021 \\
\hline & Within Groups & 759.986 & 763 & .996 & & \\
\hline & Total & 776.490 & 770 & & & \\
\hline \multirow[t]{3}{*}{ Non-intellective } & Between Groups & 13.947 & 7 & 1.992 & 1.792 & .086 \\
\hline & Within Groups & 848.538 & 763 & 1.112 & & \\
\hline & Total & 862.485 & 770 & & & \\
\hline
\end{tabular}


As can be gleaned from Table 8, preservice teachers' overall SATT (F2.655=, p-value $=.010)$ performance registered a significant difference. Post tests revealed that BSEd-English students had better overall SATT performance than the rest of the students.

Table 8. Analysis of Variance (ANOVA) on the preservice teachers' SATT performance when grouped according to their field of specialization (Overall)

\begin{tabular}{llrrrrr}
\hline & $\begin{array}{c}\text { Sums } \\
\text { of squares }\end{array}$ & \multicolumn{1}{c}{ df } & $\begin{array}{c}\text { Mean } \\
\text { Square }\end{array}$ & F & Sig. \\
\hline SATT & Between Groups & 12.097 & 7 & 1.728 & 2.655 & .010 \\
& Within Groups & 496.575 & 763 & .651 & & \\
& Total & 508.672 & 770 & & & \\
\hline
\end{tabular}

\section{Discriminant Analysis}

This section presents and interprets the results of the discriminant analysis meant to find out what discriminant model could best explain preservice teachers' academic achievement. The final variables entered in the model were numerical, verbal (SATT constructs), abstract and general information (USePAT constructs). Variables not found in the table are non-significant factors (Table 9). 
Table 9. Discriminant analysis of variables

\begin{tabular}{|c|c|c|c|c|c|c|c|c|c|}
\hline \multicolumn{10}{|c|}{ Variables Entered/Removed ${ }^{\mathrm{a}, \mathrm{b}, \mathrm{c}, \mathrm{d}}$} \\
\hline \multirow[t]{3}{*}{ Step } & \multirow[b]{3}{*}{ Entered } & \multirow{2}{*}{\multicolumn{8}{|c|}{ Wilks' Lambda }} \\
\hline & & & & & & & & & \\
\hline & & Stats & df1 & df 2 & df3 & Stats & df1 & df 2 & Sig. \\
\hline 1 & numerical & .904 & 1 & 2 & 768.00 & 40.603 & 2 & 768.00 & .00 \\
\hline 2 & verbal & .869 & 2 & 2 & 768.00 & 27.921 & 4 & 1534.00 & .00 \\
\hline 3 & $\begin{array}{l}\text { usepat_ } \\
\text { abstract }\end{array}$ & .858 & 3 & 2 & 768.00 & 20.326 & 6 & 1532.00 & .00 \\
\hline 4 & $\begin{array}{l}\text { usepat_- } \\
\text { gen info }\end{array}$ & .848 & 4 & 2 & 768.00 & 16.405 & 8 & 1530.00 & .00 \\
\hline
\end{tabular}

At each step, the variable that minimizes the overall Wilks' Lambda is entered.

a. Maximum number of steps is 40 .

b. Minimum partial $\mathrm{F}$ to enter is 3.84 .

c. Maximum partial $\mathrm{F}$ to remove is 2.71 .

An eigenvalue (Table 10) indicates the proportion of variance explained. (Between-groups sums of squares divided by within-groups sums of squares). A large eigenvalue is associated with a strong function. The canonical relation is a correlation between the discriminant scores and the levels of the dependent variable. A high correlation indicates a function that discriminates well. The present correlation is not extremely high (1.00 is perfect); function 1 has canonical correlation of .378, while function 2 has canonical correlation of .102 .

Table 10. Summary of canonical discriminant functions

\begin{tabular}{lrrrrr}
\hline \multirow{2}{*}{ Function } & \multicolumn{2}{c}{ Eigenvalues } & & \\
& & Eigenvalue & $\%$ of Variance & $\begin{array}{c}\text { Cumulative } \\
\%\end{array}$ & $\begin{array}{c}\text { Canonical } \\
\text { Correlation }\end{array}$ \\
\hline \multirow{2}{*}{ dimension0 } & 1 & $.167^{\mathrm{a}}$ & 94.1 & 94.1 & .378 \\
& 2 & $.011^{\mathrm{a}}$ & 5.9 & 100.0 & .102 \\
\hline
\end{tabular}

a. First 2 canonical discriminant functions were used in the analysis. 
A small lambda (see Table 11) indicates that group means appear to differ. The associated significance value indicates whether or not the difference is significant. Here, the Lambda has significant value (Sig.=0.000); thus, the group appears to differ.

Table 11. Test of functions using Wilk's Lambda

\begin{tabular}{crrrrr}
\hline Test of Function(s) & \multicolumn{2}{c}{$\begin{array}{c}\text { Wilks' Lambda } \\
\text { Wilks' } \\
\text { Lambda }\end{array}$} & Chi-square & df & \multicolumn{1}{c}{ Sig. } \\
\hline dimension0 & 1 through 2 & .848 & 126.158 & 8 & .000 \\
\hline & 2 & .990 & 8.012 & 3 & .046 \\
\hline
\end{tabular}

First two factors loaded high in function 2, while the last two loaded high in function 1 (Table 12).

Table 12. Standardized canonical discriminant function coefficients

\begin{tabular}{lrr}
\hline & Function & \\
& $\mathbf{1}$ & $\mathbf{2}$ \\
\hline usepat_gen_info & .243 & -.536 \\
usepat_abstract & .201 & .850 \\
satt_verbal & .513 & .106 \\
satt_numerical & .567 & -.416 \\
\hline
\end{tabular}

Table 13 shows the functions at group centroids. The students' academic achievements were categorized according to high, average and low.

Table 13. Functions at group centroids

\begin{tabular}{lllr}
\hline final_grade2 & & \multicolumn{2}{c}{ Function } \\
& & $\mathbf{1}$ & \multicolumn{1}{c}{$\mathbf{2}$} \\
\hline dimension0 & High & .659 & -.063 \\
\hline & average & -.132 & .079 \\
& low & -.541 & -.190 \\
\hline
\end{tabular}

Unstandardized canonical discriminant functions evaluated at group means 
Group covariances of canonical discriminant functions

\begin{tabular}{|c|c|c|c|c|c|}
\hline \multicolumn{2}{|l|}{ final_grade2 } & \multicolumn{2}{|l|}{ Function } & 1 & 2 \\
\hline \multirow{6}{*}{ dimension0 } & \multirow[t]{2}{*}{ High } & \multirow{2}{*}{ dimension1 } & 1 & 1.002 & -.052 \\
\hline & & & 2 & -.052 & 1.047 \\
\hline & \multirow[t]{2}{*}{ Average } & \multirow[b]{2}{*}{ dimension 1} & 1 & .993 & $-3.995 \mathrm{E}-5$ \\
\hline & & & 2 & $\begin{array}{r}-3.995 \mathrm{E}- \\
5\end{array}$ & .951 \\
\hline & \multirow[t]{2}{*}{ Low } & \multirow{2}{*}{ dimension 1} & 1 & 1.023 & .081 \\
\hline & & & 2 & .081 & 1.107 \\
\hline
\end{tabular}

The pooled within-groups covariance matrix of the canonical discriminant functions is an identity matrix by definition.

Presented in Table 14 is the lesser difference in group's covariance matrix and the relatively equal determinants in the three (3) performance levels. The "Rank" column indicates the number of independent variables considered which is two (2) in this case. Since discriminant analysis assumes homogeneity of covariance matrices between the performance levels, the determinants are relatively equal.

Table 14. Log determinants of the Box's test of equality of covariance matrices

\begin{tabular}{lcr}
\hline \multicolumn{3}{c}{ Log determinants } \\
\hline final_grade2 & Rank & Log Determinant \\
\hline High & 2 & .045 \\
average & 2 & -.057 \\
low & 2 & .119 \\
(identity matrix) & 2 & .000 \\
\hline
\end{tabular}

The ranks and natural logarithms of determinants printed are those of the group covariance matrices of the canonical discriminant functions. 
Table 15 shows the qualification of the entered data to multivariate normality assumptions. Multivariate normality ties back to all variables being normally distributed on a univariate level where the threshold is 0.01 . As can be gleaned from Table 15 , the p-value $=.850$ is greater than 0.01 , the recommended threshold, thus not significant. The criteria of multivariate normality were met and any normality assumptions were dishonored.

Table 15. Box's M test results

\begin{tabular}{llr}
\hline \multicolumn{3}{c}{ Test results } \\
\hline Box's M & & 2.673 \\
\hline $\mathrm{F}$ & Approx. & .443 \\
\cline { 2 - 3 } & df1 & 6 \\
\cline { 2 - 3 } & df2 & 1409069.577 \\
\cline { 2 - 3 } & Sig. & .850 \\
\hline
\end{tabular}

Tests null hypothesis of equal population covariance matrices of canonical discriminant functions.

Table 16 shows the probability of landing at the three (3) performance levels if USePAT and SATT shall be conducted to the student respondents.

Table 16. Prior probabilities for groups

\begin{tabular}{llrrr}
\hline final_grade2 & & \multicolumn{3}{c}{ Cases Used in Analysis } \\
& & Prior & Unweighted & Weighted \\
\hline \multirow{3}{*}{ dimension0 } & High & .250 & 193 & 193.00 \\
& Average & .589 & 454 & 454.00 \\
& Low & .161 & 124 & 124.00 \\
& Total & 1.000 & 771 & 771.00 \\
\hline
\end{tabular}


Figures 2, 3 and 4 show the visual representation of the student respondents' performance level in their final grade in terms of the discriminant variables. The discriminant model when the final grades of the student respondents were analyzed showed that numerical and verbal (SATT constructs) and abstract reasoning and general information (USePAT constructs) contribute significantly to the prediction of the performance of the student respondents. The group centroids are more or less distant from each other, thus the errors of classification are unlikely.

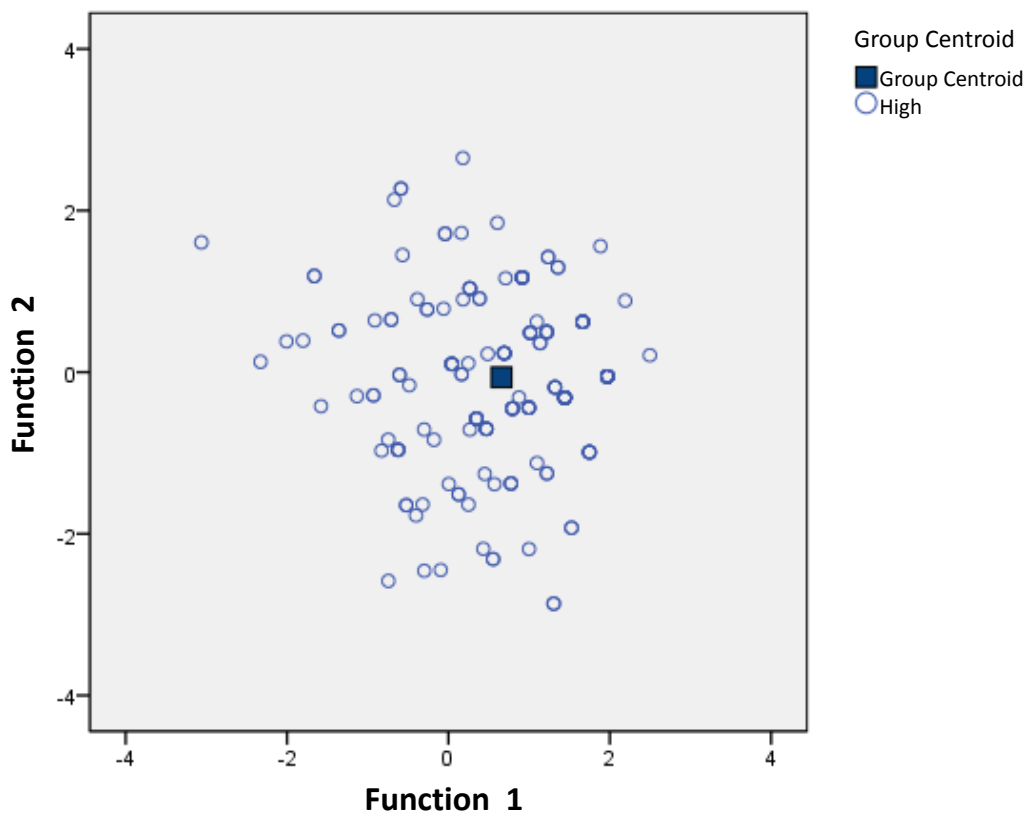

\section{Figure 2}

Canonical discriminant functions for students with High Performance

Average performing group tends to show high competence in discriminant function2 variables (USePAT constructs - general information and abstract). 


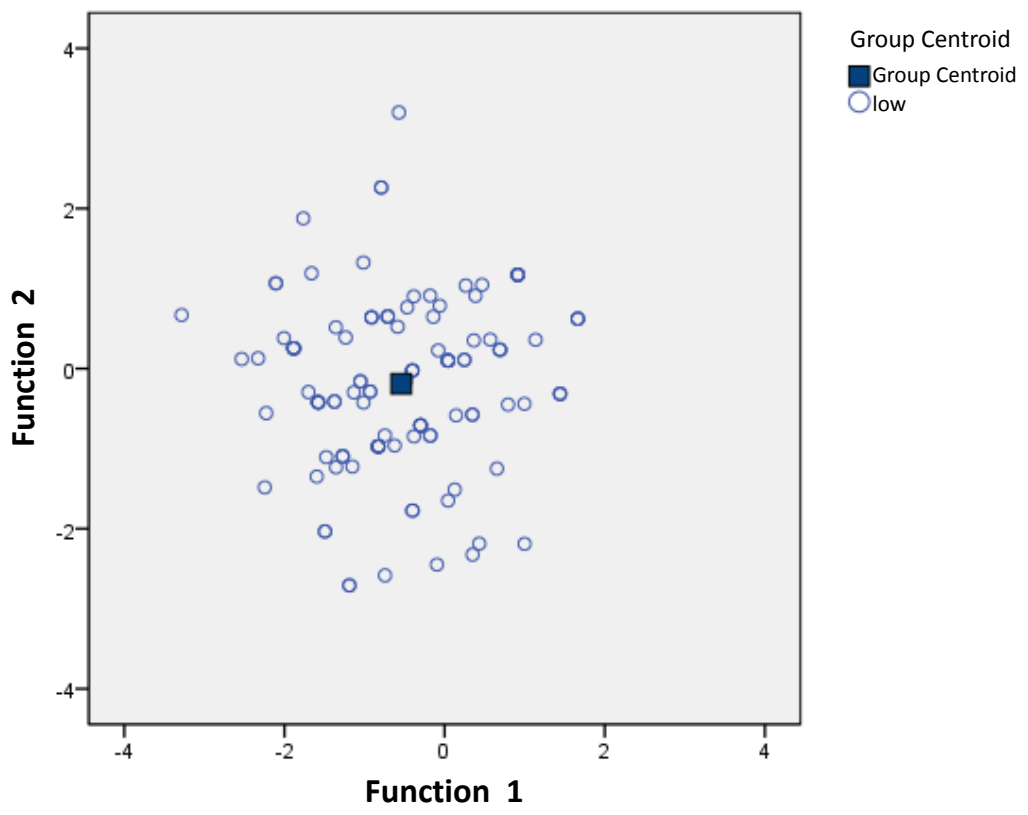

Figure 3

Canonical discriminant functions for students with Low Performance

Low performing group tends to show high competence in discriminant function2 variables (USePAT constructs - general information and abstract). 


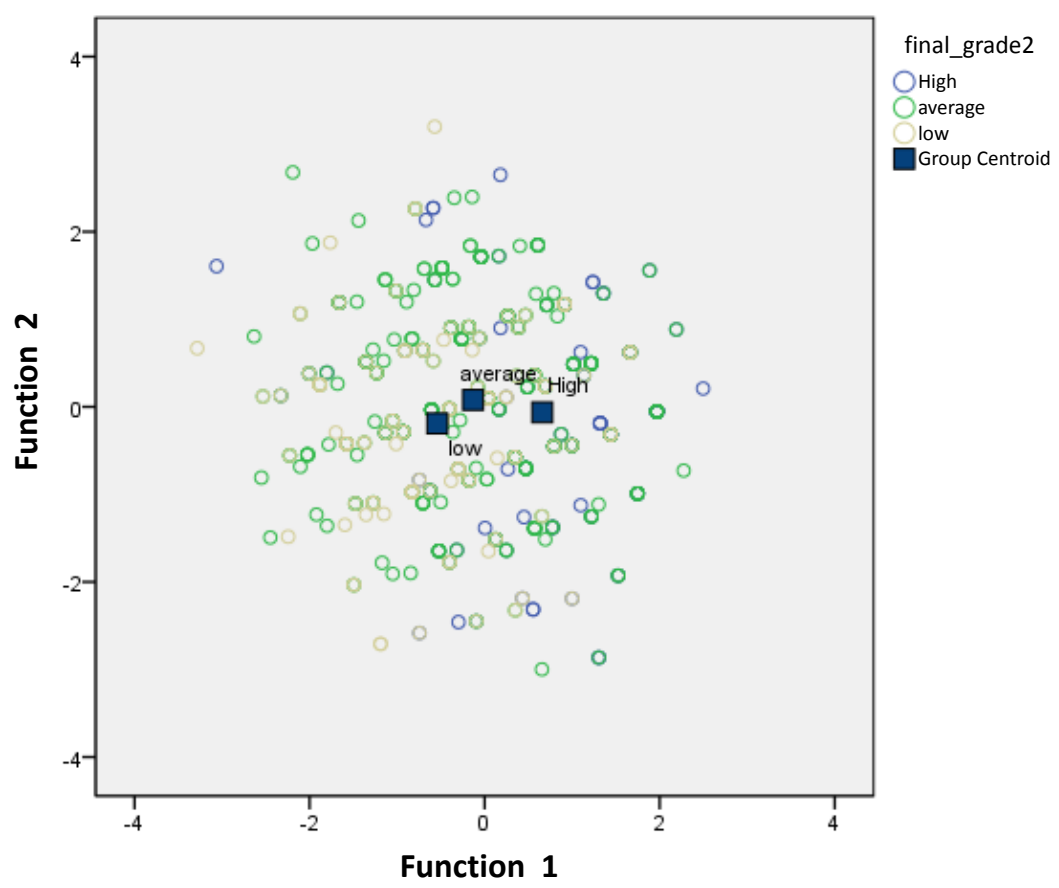

Figure 4

Canonical discriminant functions for students across groups

Average and low performing students tend to show higher rating in the variables under function2 (USePAT constructs - general information and abstract). High performing group showed higher rating on factors under functionl (SATT constructs - verbal and numerical). 
Presented in Table 17 is the magnitude of the predictability of numerical and verbal (SATT) and abstract and general information (USePAT) variables to the final grades of the student respondents.

Table 17. Classification results.

\begin{tabular}{|c|c|c|c|c|c|c|c|}
\hline \multicolumn{8}{|c|}{ Classification Results $^{\mathrm{a}}$} \\
\hline & & \multirow{2}{*}{\multicolumn{2}{|c|}{ final_grade2 }} & \multicolumn{3}{|c|}{$\begin{array}{l}\text { Predicted Group } \\
\text { Membership }\end{array}$} & \multirow[b]{2}{*}{ Total } \\
\hline & & & & High & Average & Low & \\
\hline \multirow[t]{6}{*}{ Original } & \multirow[t]{3}{*}{ Count } & & High & 59 & 134 & 0 & 193 \\
\hline & & dimension2 & Average & 38 & 413 & 3 & 454 \\
\hline & & & Low & 7 & 112 & 5 & 124 \\
\hline & \multirow[t]{3}{*}{$\%$} & & High & 30.6 & 69.4 & .0 & 100.0 \\
\hline & & dimension 2 & Average & 8.4 & 91.0 & .7 & 100.0 \\
\hline & & & Low & 5.6 & 90.3 & 4.0 & 100.0 \\
\hline
\end{tabular}

a. $61.9 \%$ of original grouped cases correctly classified.

\section{Summary of Findings and Recommendations}

The following summarized findings from the study were drawn: (a) generally students who were accepted to join the ranks of preservice teachers were average students, based on their USePAT scores; (b) they earned high average in the SATT constructs, except in Judgment and teaching situation where they were considered low average; (c) generally, BSEd-English, Math and Biology students had better ratings in USePAT and SATT; and (d) numerical, verbal (SATT constructs), abstract and general information (USePAT constructs) are variables that could discriminate students' academic achievement.

It is recommended that top management of the University should revisit the entry requirements for preservice teachers considering better ratings for English, Math and Science as results for those did not figure 
in the discriminant model. Teachers, upon knowledge of these findings should likewise examine the causes of students' having low average in Judgment and teaching situation (SATT constructs), especially so that negative implications might manifest in their future profession. Finally, since discriminant analysis is proven to be a helpful tool in this area of study, future researchers may consider doing a duplicate investigation using the tool, such as finding out which discriminant model could explain achievement in licensure examination for teachers or other education-related research phenomena. 


\section{References}

Ambag, S.C. (2015). Assessment of competency level of preservice teachers based on National Competency-Based Teacher Standards (NCBTS) in public school in the national capital region. European Academic Research Vol. II, Issue 11. ISSN 2286-4822 www. euacademic.org

Chapter 440 Discriminant Analysis. (n.d.) Retrieved from https:/ / tinyurl. com/y2jwaok6 on October 5, 2016.

DepEd Order No. 42, s., 2017. National adoption and implementation of the Philippine Professional Standards for Teachers. Available at: https:/ / tinyurl.com/y4467w6a

Hall, P.C., \& West, J.H. (2011). Potential predictors of student teaching performance: Considering emotional intelligence. Issues in Educational Research, 21(2). Retrieved from http://www.iier.org.au/ on October 5, 2016.

Williams, C. (2007). Research methods. Journal of Business \& Economic Research. Volume 5, Number 3

Wright, V.J. (2015). Is ATAR useful for predicting the success of Australian Students in initial teacher education? Australian Journal of Teacher Education. Volume 40, Issue 9. Retrieved from http:/ / ro.ecu. edu.au/ on October 5, 2016 